\title{
IAMJ
}

INTERNATIONAL

AYURVEDIC

MEDICAL JOURNAL

\section{AN OBSERVATIONAL CROSS-SECTIONAL STUDY TO EXPLORE THE VAIKALYAKARA EFFECT OF JANU MARMA THROUGH ANATOMICAL CONSIDERATIONS OF KNEE JOINT INJURIES RELATED TO SPORTS}

\section{Nivil K P}

Assistant Professor, Department of Rachana Shareera, Vishnu Ayurveda College, Shoranur, Kerala, India

Corresponding Author: nivilkp@gmail.com

\section{https://doi.org/10.46607/iamj01p5012020}

(Published online: November 2020)

Open Access

(C) International Ayurvedic Medical Journal, India 2020

Article Received: 17/10/2020 - Peer Reviewed: 03/11/2020 - Accepted for Publication: 08/11/2020

\section{Check for updates}

\begin{abstract}
Introduction: The aim of the study was to determine the time to and rate of the return to sports (RTS) after knee joint injury. The data obtained was analysed to fine line the commonly affected anatomical entity responsible and to correlate with Janumarma. Methodology: The symptoms assessed from the case proforma and MRI were compared to the Janu Marmabhighatha Lakshanas. The grading of injury and Khanjatha was determined with the help of unique scoring adapted for the study. Results: Based on literary review Khanjatha can be defined as a weakness in limbs resisting its complete functional mobility. Anterior Cruciate Ligament (ACL) was found to be the most vulnerable structure. Cadaveric dissection studies showed the morphological significance of ACL to be placed as a Kandara has been surmised. Conclusion: Khanjatha is concluded as the difficulty in regaining complete functional mobility, which was observed in $70 \%$ of ACL injuries highlighting the plausible correlation of ACL as Janumarma.
\end{abstract}

Keywords: Sports injury, Khanjatha, Janu marma 


\section{INTRODUCTION}

The concept of Marma Shareera though discussed widely for its therapeutical implications, leaves us a wide arena of untapped resources as diagnostic and prognostic tools. Its multitude of venues which is highly resourceful even in emergency management and sports medicine is yet to be utilized in a broader perspective. Sports persons often face the challenge of reduced competence following injuries despite of ultra-modern medical assistance. Reconstructive and rehabilitation therapies followed in sports medicine is having relatively limited curative rates especially in knee joint injuries. Conclusively the rate of players returning to competitive sports post trauma is alarmingly low. In this context it is simply logical to apply the prognostic views of Acharya Susrutha about the Janumarma and its Abhigatha in the light of modern radiological imaging techniques. Based on these views, treatment protocol could be devised incorporating all the possibilities of Ayurvedic approach in Marmachikitsa to provide a better alternative for surgically reluctant patients in this evolving medical world.

\section{Aim of The Study}

1. To establish the true implication of Vaikalya (Khanjatha) explained by Acharya Susrutha in the context of Janumarmabhighata

2. To identify the most vulnerable part of Janu sandhi which when injured results in Khanjatha and there by establish it as a plausible correlation for Janu marma.

\section{Methodology}

Study setting: Department of Rachana Shareera, Alvas Ayurveda College, Moodbidri

Study was planned in 4 phases

\section{Phase 1: Literary and conceptual study}

Included data compilations from Bruhatrayee, Laghuthrayee and other classical books including journals, presented papers, previous work done

Phase 2: Detailed study of Janu Sandhi Shareera with the help of cadaveric dissection

Dissection of Janu sandhi was carried out in cadavers to determine anatomical structures contributing to Janu Marma
Phase 3: Study based on clinical observations

Carried out in Diasman sports clinic Kondotty under the guidance of Dr. Arshad.

Phase 4: Radiological study

Based on MRI and supporting evidence from xrays Sample size: 30

Inclusion Criteria: Patients diagnosed with injuries to knee related to sports., $\mathrm{H} / \mathrm{o}$ trauma within a minimum duration of 6 months. Age group- 15 to 35 years. Exclusion Criteria: Patients suffering from arthritic disorders., Patients having any congenital joint anomalies.

Assessment Criteria: Informed consent was obtained from patients, A detailed case format (Rugna patrika) was prepared to assess the precipitating complaints in knee joint injury cases and compared it to Janumarmabhigatha lakshana explained in classics. The injured structure and the grade of injury was determined on the basis of collected MRI reports and analysed. The severity of Khanjatha was determined with the help of a unique scoring adapted for the study based on which the data was collected through systematic follow up.

\section{Results}

\section{Literary Review}

Based on the considerations and deliberations of references compiled from Bruhatrayee the literary implications of Khanjatha can be generalised from a visible limping to any weakness interfering the joint's return to its functional rigour.

Also, Vaghbata highlights the involvement of Kandara in development of Khanjatha.

\section{Cadaveric Dissection}

On careful examination of dissected specimens, it was observed that the appearance of ACL is morphologically meeting the criteria for the Ayurvedic classification of kandara i.e. Vrutha Snayu.

\section{Radiological Findings}

Majority of the cases shows involvement of ACL alone or with meniscus or adjoining ligaments. 


\section{Graph 1: Distribution of Khanjatha}

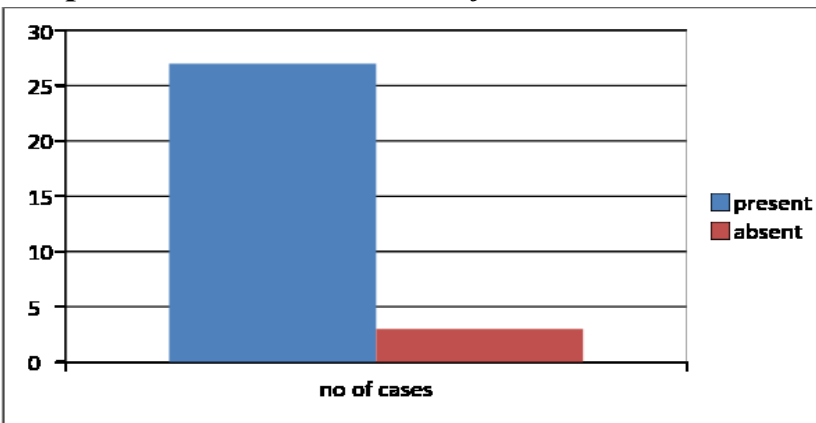

27 among 30 cases shows presence of Khanjatha when returning to sports (RTS), 3 patients has no significant Khanjatha observed.

Graph 2: Distribution According to Degree of Khanjatha

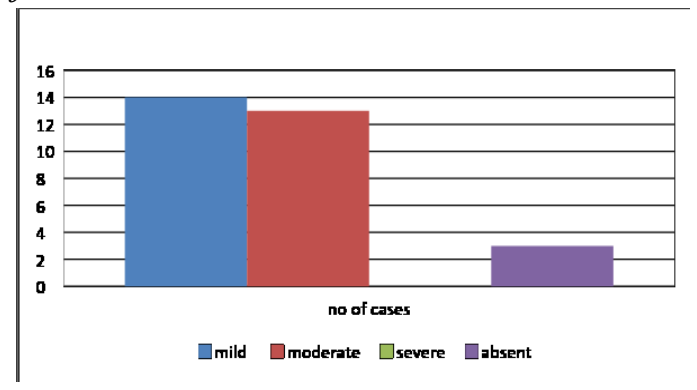

Khanjatha was found to be absent for 3 patients, 14 patients showed mild Khanjatha and 13 showed moderate Khanjatha. No patients reported severe Khanjatha.

Graph 3: Comparison of Khanjatha Score with Radiological Findings

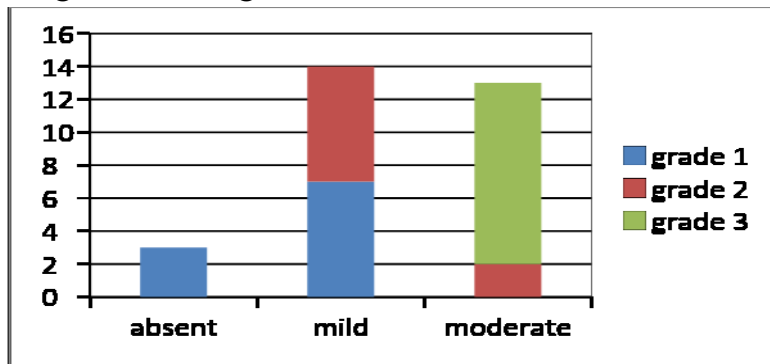

Among patients who were reported no Khanjatha, $10 \%$ were having grade 1 injury, $50 \%$ of patients who reported mild Khanjatha had grade 1 injury while the other $50 \%$ had grade 2 injury. Among patients who had moderate Khanjatha, $15.3 \%$ of them were having grade 2 injury, $84.6 \%$ were having grade 3 injury.

Table 1: Comparison of Khanjatha score with distribution based on injured structure

\begin{tabular}{|l|l|l|l|l|}
\hline Structure involved & Mild & Moderate & Absent & Total \\
\hline ACL & 7 & 3 & 0 & 10 \\
\hline ACL, MCL & 1 & 0 & 0 & 1 \\
\hline Medial Meniscus & 0 & 0 & 1 & 1 \\
\hline Lateral Meniscus & 1 & 0 & 2 & 3 \\
\hline ACL, Medial Meniscus & 1 & 6 & 0 & 7 \\
\hline ACL, Lateral Meniscus & 3 & 2 & 0 & 5 \\
\hline MCL, Medial Meniscus & 1 & 0 & 0 & 1 \\
\hline ACL, MCL, Lateral Meniscus, LCL & 0 & 1 & 0 & 1
\end{tabular}

Graph 4: Comparison of Khanjatha score with distribution based on injured structure

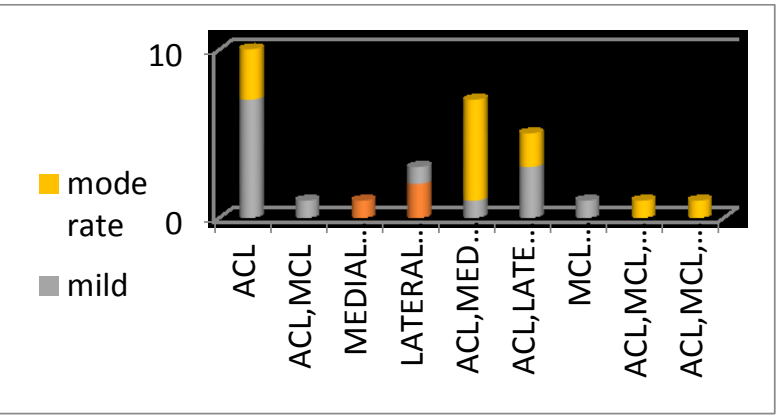


Table 2: Severity of Khanjatha based on injured structure

\begin{tabular}{|l|l|}
\hline Injured structure & Severity of Khanjatha \\
\hline Only ACL & $70 \%$-mild Khanjatha \\
\hline \multirow{2}{*}{ ACL \& medial meniscal injury } & $30 \%$-moderate Khanjatha \\
\hline Involving ACL \& lateral meniscus & $85.7 \%$ - mild Khanjatha \\
\hline Involving lateral meniscal tear. & $14.3 \%$-moderate Khanjatha \\
\hline & $60 \%$ - mild Khanjatha \\
\hline & $40 \%$-moderate Khanjatha \\
\hline & $90 \%$ - no Khanjatha \\
\hline & $10 \%$ - mild Khanjatha \\
\hline
\end{tabular}

\section{DISCUSSION}

In the light of literary analysis, we can specify the term Khanjatha to a weakness of the Janu sandhi to return to its full-fledged functions there by influencing their RTS. 83\% of the cases shows involvement of ACL alone or with meniscus or adjoining ligaments. Altogether 25 patients show involvement of ACL ligament in which $40 \%$ involves only ACL and the rest shows involvement of meniscus \& collateral ligaments. All the patients involving ACL injury shows mild or moderate Khanjatha. Also, there is reference regarding the involvement of Kandara in developing Khanjatha. This signifies the findings in cadaveric studies providing morphological evidence to assume that ACL could be classified as a Vrutha Sna$y u /$ Kandara. The severity of the Khanjatha and the rate of RTS is invariably depending on the grade of injury, among which $84.3 \%$ of grade 3 injury showing moderate Khanjatha in grade 2 injury $65.3 \%$ and in grade $150 \%$ of cases were presenting Khanjatha a miniscule of $10 \%$ was showing absence of Khanjatha ,in injuries related to menisci. In the light of above told postulations we may contemplate that cruciate ligaments are the commonly injured structure \& cases with ACL injury symptomatically resemble Janumarmabhigatha.

\section{CONCLUSION}

Among the sample size of 30 the injuries involving ACL showed a total of $40 \%$ mild and $43 \%$ moderate Khanjatha. None showed severe Khanjatha which means visible impairment affecting gait. This summarises the fact that even if the acute symptoms associat- ed is relieved considerably due to timely intervention the person finds it difficult to return to competitive sports, which is exactly the prognosis mentioned by Susrutha in the definition of Vaikalyakara Marma. Hence, we may conclude that the anatomical structure involved in Janumarmabhighata is ACL.

\section{Clinical Relevance}

Outcomes following anterior cruciate ligament (ACL) injury are considered poor even after timely intervention. The study provides us ample evidence to ascertain that Marmabhighata Chikitsa protocol should be devised and followed in managing such conditions and educating the patients about the impending complications will be a positive approach.

\section{REFERENCES}

1. Sushruta. Sushruta Samhita with Nibanda Sangraha Commentary of Dalhana Acharya. Edited by Vaidya Jadavji Trikamji Acharya, 7th edition. Varanasi: Chaukhambha Orientalia; 2002. Pp824, Page no: 150 (Su.35 /12).

2. Sushruta. Sushruta Samhita with Nibanda Sangraha Commentary of Dalhana Acharya. Edited by Vaidya Jadavji Trikamji Acharya, 7th edition. Varanasi: Chaukhambha Orientalia; 2002. Pp824, page no 370, sloka $6 / 12$.

3. Agnivesha. Charaka Samhita with Ayurveda Deepika Commentary of Chakrapanidatta. Edited by Vaidya Jadavji Trikamji Acharya, 5th edition. Page 170 Varanasi: Chaukhambha Sanskrit Sansthana; 2001. Pp738, Page no: 279 (Vi.8 / 117).

4. Agnivesha Charaka Samhitha revised by Charaka and Dridhabala with the Ayurvedadipika commentary of Chakrapani Dutta edited by Vaidya Yadvaji Trikamji 
acharya. Published by Chaukhamba Sanskrit series, fourthedition.1994. Sloka 6, Page no 337.

5. Acharya Vriddha jivaka. Kasyapa samhitha or vriddhajivakiya tantra edited by P V Tewari. Published by Chaukhambha visvabharati, reprint 2008, sloka 5 Page no 125 .

6. Acharya Vriddha Vagbhata, Astanga Samgraha with Sasilekha Sanskrit commentary by Indu edited by Dr.Kavi raj atri deva gupta, Chaukhambha Sanskri series Varanasi first Edition 2005, sloka no 77, page no. 305 .

7. Pandit Sharangadhara Acharya. Sharangadhara Samhita with the Adhamalla's Dipika Commentary and Kashirama's Gudartha Dipika. Edited by Pandit Parasurama Shastri, 5th edition. Varanasi: Chaukhambha Orientalia; 2002. Pp 398, Page no: 52 (Pratama Khanda5 / 37).

8. Vriddha Vagbhata. Shiv Prasad Sharma, editor. Ashtanga Sangraha with Sasilekha commentary of Indu. 1st ed Varanasi: Choukhamba Sanskrit series office; 2006. Pp- 965, p- 390.

9. Vagbhata. Harisadasivasastri Paradakara Bhisagacarya, editor. Ashtanga Hrudaya with Sarvangasundari of Arunadatta \& Ayurvedarasayana of Hemadri. Varanasi: Chouhkamba Surbharathi Prakashan; 2007. Pp-956, p- 409.

10. Vruddha Jeevaka. Kasyapa Samhita or Vruddha Jeevaka Tantra, revised by Vatsya with Sanskrit introduction by Nepal Rajaguru Pandit Hemaraja Sharma. 7th ed. Varanasi: Choukamba Sanskrit Samsthan. Pp364, p- 76.

11. Bhavamishr. Brahma Shankar Misra, editor. Bhavaprakasha Part I with Hindi commentary by Pandit Sri. Brahma Shankar Misra. 8th ed. Varanasi: Chaukambha Sanskrit Sansthan; 2003. Pp: 960; p. 66.

12. Radakant dev. Varada Prasad, editor. Shabda kalpa druma. Vol 5. ed. Delhi: Naga publishers; 1987. Pp792, p-102.

13. Vagbhata's Ashtanga Hrudayam Translated By Prof K R Srikantha Murthy Chowkamba Krishnadas Academy, Varanasi, Reprinted 2010, Slokha Number 45, P.156

14. https://www.ncbi.nlm.nih.gov/pmc/articles/PMC45380 $02 /$

15. https://www.ncbi.nlm.nih.gov/pmc/articles/PMC54888 $39 /$

\section{Source of Support: Nil}

\section{Conflict of Interest: None Declared}

How to cite this URL: "An Observational Cross-Sectional Study To Explore The Vaikalyakara Effect Of Janu Marma Through Anatomical Considerations Of Knee Joint Injuries Related To Sports". International Ayurvedic Medical Journal \{online\} 2020 \{cited November, 2020\} Available from: http://www.iamj.in/posts/images/upload/2549 2553.pdf 